\title{
PENGARUH KETEPATAN WAKTU PENYAMPAIAN LAPORAN KEUANGAN, KELEMAHAN SISTEM PENGENDALIAN INTERNAL, KEPATUHAN PERATURAN PERUNDANG-UNDANGAN, STATUS DAERAH DAN UKURAN DAERAH TERHADAP OPINI LAPORAN KEUANGAN PEMERINTAH DAERAH DI PULAU JAWA TAHUN 2013
}

\author{
Samsul Rosadi $^{1}$, Yudi Siyamto ${ }^{2}$, Helti Nur Aisyiah ${ }^{3}$ \\ 1) IAIN Surakarta, Jawa Tengah, Email: samsul.rosadi@gmail.com \\ ${ }^{2}$ STIE-AAS Surakarta, Jawa Tengah, Email: yudi.stieaas@gmail.com \\ ${ }^{3)}$ IAIN Surakarta, Jawa Tengah, Email: aisyah76@gmail.com
}

\begin{abstract}
This study aims to examine the effect of timely delivery of financial statements, weaknesses of internal control systems, compliance with statutory regulations, regional status and size of the region on the opinion of local government financial reports on the island of Java. By using LKPD 110 the city / regency government in Java Island. Sampling technique is purposive sampling, that is how to determine sample by using certain criterion. Hypothesis testing techniques using logistic regression analysis. The results of this study indicate that the variable timeliness of financial reporting, weakness of the internal control system, compliance with legislation has a negative effect on the opinion of local government financial statements. While the variables of regional status and size of the regions have no effect on the opinion of local government financial statements.
\end{abstract}

Keywords: timeliness of financial report submission, weakness of internal control system, regulatory compliance, regional status, regional size and opinion of local government financial report

\section{Pendahuluan}

Badan Pemeriksa Keuangan (BPK) bertugas untuk memeriksa Laporan Keuangan Pemerintah Daerah (LKPD) setiap tahun. Jadi setiap tahun pemerintah daerah harus membuat laporan keuangan yang nantinya akan diaudit oleh BPK. Hal ini sesuai dengan Permendagri No. 13 Tahun 2006 yaitu mewajibkan kepala daerah (gubernur/bupati/walikota) untuk menyampaikan LKPD kepada BPK dalam waktu tiga bulan setelah tahun anggaran berakhir. Sementara itu, UU No. 15 Tahun 2004 memberikan waktu (paling lambat) dua bulan kepada BPK untuk melakukan pemeriksaan terhadap LKPD untuk kemudian BPK menyerahkan LHP atas LKPD tersebut kepada DPRD. Berdasarkan peraturan tersebut, diharapkan BPK dapat menyelesaikan tugas pengauditan dengan tepat waktu paling lambat dua bulan.

Laporan hasil pemeriksaan atas laporan keuangan pemerintah daerah merupakan pernyataan atau opini auditor atas laporan keuangan yang disusunlah pemerintah daerah. Laporan hasil pemeriksaan auditor harus memuat suatu pernyataan pendapat atas laporan keuangan secara keseluruhan atau memuat asersi, bahwa pernyataan demikian tidak dapat diberikan. Jadi, laporan auditor adalah pemyataan pendapat auditor atas pemeriksaan yang telah dilakukan. Dalam audit atas laporan keuangan, pemakai laporan keuangan dapat melihat kewajaran laporan keuangan pemerintah daerah dengan melihat laporan auditor. Laporan auditor adalah petunjuk yang memberikan informasi bagi pengguna laporan misalnya bagi DPRD, masyarakat, pemerintah pusat dan pemakai lainnya (Haryanto,Sahmuddin dan Arifuddin, 2007).

Hasil dari pemeriksaan BPK tahun 2013 masih banyak pemerintah daerah yang mendapat opini audit yang tidak wajar. Berikut data opini audit BPK pada Laporan Hasil Pemeriksaan BPK tahun 2013. 
JURNAL ILMIAH EKONOMI ISLAM VOL. 03 NO. 02, Juli 2017

Available at http://jurnal.stie-aas.ac.id/index.php/jie

Rangkuman Hasil Pemeriksaan BPK RI

\begin{tabular}{ll}
\hline Opini Badan Pemeriksa Keuangan & Jumlah \\
\hline Disclaimer & 17 \\
Tidak Wajar & 8 \\
Wajar Dengan Pengecualian & 269 \\
Wajar Tanpa Pengecualian & 134 \\
\hline Jumlah & 426 \\
\hline
\end{tabular}

Data yang diolah 2013

Menurut McLellan dan Giroux (2000), opini wajar dengan pengecualian (qualified opinion) merupakan sebuah anggapan yang buruk bagi pengguna laporan keuangan. Hasil penelitian Payne dan Jensen (2000) menyebutkan opini wajar dengan pengecualian berpengaruh positif terhadap audit delay. Opini yang diberikan oleh BPK atas laporan keuangan pemerintah daerah berupa opini dapat dianggap sebuah catatan buruk kinerja keuangan pemerintah daerah yang bersangkutan. Opni selain WTP yaitu WDP, tidak wajar dan disclaimer mengindikasikan bahwa pemerintah daerah tidak dapat menyusun laporan keuangan sesuai dengan SAP.

Pemeriksa BPK dalam melaksanakan tugasnya membuat suatu laporan hasil pemeriksaan keuangan berupa opini serta serta laporan hasil pemeriksaan atas SPI di lingkungan entitas pemeriksaan. Unsur-unsur pengendalian intern dalam SPIP digunakan sebagai alat untuk melakukan evaluasi atas pengendalian intern pada pemerintah daerah. Hasil pemeriksaan BPK dituangkan dalam LHP dan dinyatakan dalam sejumlah temuan. Setiap temuan dapat terdiri atas satu atau lebih permasalahan kelemahan SPI dan/atau ketidakpatuhan terhadap ketentuan perundangundangan. Efektivitas SPI merupakan salah satu kriteria yang digunakan oleh BPK dalam meneliti kewajaran informasi keuangan, sesuai dengan Undang-undang nomor 15 Tahun 2004, penjelasan pasal 16 ayat (1). Hal ini mengindikasikan bahwa proses pemahaman SPI memiliki peran penting dalam penentuan keputusan pemeriksaan, mulai dari penyusunan rencana pemeriksaan hingga keputusan pemberian opini atau kesimpulan akhir pemeriksaan.

Selain sistem pengendalian intern, auditor juga mempertimbangkan kepatuhan terhadap ketentuan peraturan perundang-undangan dalam melakukan pemeriksaannya. Bagi auditor dalam memberikan pendapatnya tidak hanya meyakini bahwa laporan keuangan dengan gambaran telah disajikan secara benar dan jujur serta sesuai dengan standar akuntansi semata tetapi juga mempertimbangkan relevansinya terhadap undang-undang (CPA Australia Ltd, 2013). Karena laporan keuangan khususnya untuk sektor publik juga harus dapat memberikan jaminan kepada pengguna laporan keuangan dan otoritas penguasa tentang pengelolaan sumber daya yang dilakukan telah memenuhi ketentuan hukum yang ditetapkan (Mardiasmo, 2002: 125). Penelitian Jiang et.al (2009) menunjukkan bahwa terdapat hubungan positif antara pengungkapan kelemahan SPI yang material dan kecenderungan auditor untuk mengeluarkan opini going concern. Penelitian Tuti Herawati (2014) menemukan bahwa sistem pengendalian intern berpengaruh positif dan signifikan terhadap kualitas laporan keuangan pemerintah daerah

Dari beberapa hasil penelitian terdahulu, ketidakpatuhan terhadap ketentuan peraturan perundang-undangan menyebabkan laporan keuangan pemerintah daerah belum memperoleh opini wajar tanpa pengecualian (WTP) sebagaimana dibuktikan oleh Atyanta (2011). Keterkaitan kepatuhan terhadap peraturan perundang-undangan dan efektivitas sistem pengendalian intern terhadap pemberian opini atas laporan keuangan pemerintah sudah secara jelas menjadi dasar atau kriteria pemberian opini oleh BPK RI menurut UndangUndang Republik Indonesia Nomor 15 Tahun 2004 pada penjelasan pasal 16 ayat 1 . Namun selain hal tersebut, menarik untuk dipelajari tentang konsistensi BPK RI dalam pemberian opini apakah dapat dipengaruhi oleh faktorfaktor lainnya. Misalnya dengan adanya penelitian yang menunjukkan sulitnya pemerintah daerah dalam memperoleh opini WTP disebabkan kendala penyelesaian rekomendasi tahun-tahun sebelumnya yang 
ditunjukkan dengan adanya rekomendasi tahuntahun sebelumnya yang tindaklanjutnya tidak sesuai dengan rekomendasinya dan juga terdapat rekomendasi yang belum ditindaklanjuti karena membutuhkan waktu yang lama dalam penyelesaiannya. Sehingga dari kondisi tersebut, dimungkinkan bagi pemerintah daerah untuk menerima opini audit yang sama dengan opini audit tahun sebelumnya (Atyanta, 2011).

\section{Landasan Teori}

\section{Ketepatan waktu penyampaian laporan keuangan}

Badan Pemeriksa Keuangan (BPK) bertugas untuk memeriksa Laporan Keuangan Pemerintah Daerah (LKPD) setiap tahun. Jadi setiap tahun pemerintah daerah harus membuat laporan keuangan yang nantinya akan diaudit oleh BPK. Hal ini sesuai dengan Permendagri No. 13 Tahun 2006 yaitu mewajibkan kepala daerah (gubernur/bupati/walikota) untuk menyampaikan LKPD kepada BPK dalam waktu tiga bulan setelah tahun anggaran berakhir. Sementara itu, UU No. 15 Tahun 2004 memberikan waktu (paling lambat) dua bulan kepada BPK untuk melakukan pemeriksaan terhadap LKPD untuk kemudian BPK menyerahkan LHP atas LKPD tersebut kepada DPRD. Berdasarkan peraturan tersebut, diharapkan BPK dapat menyelesaikan tugas pengauditan dengan tepat waktu paling lambat dua bulan. Ketepatwaktuan laporan keuangan tergantung pada jangka waktu audit karena laporan keuangan tidak dapat diterbitkan sebelum audit selesai dilaksanakan (Johnson, 1998).

\section{Sistem Pengendalian Internal}

Pengendalian internal didesain untuk memberikan keyakinan memadai tentang pencapaian tiga golongan tujuan yaitu keandalan pelaporan keuangan, efektivitas dan efisiensi operasi, serta kepatuhan terhadap hukum dan peraturan yang berlaku (Arens et al., 2008). Menurut PP Nomor 8 Tahun 2006 dan Permendagri Nomor 4 Tahun 2008, SPI adalah suatu proses yang dipengaruhi oleh manajemen yang diciptakan untuk memberikan keyakinan yang memadai dalam pencapaian efektivitas, efisiensi, ketaatan terhadap peraturan perundang-undangan yang berlaku, dan keandalan penyajian laporan keuangan Pemerintah.

\section{Kepatuhan terhadap Peraturan Perundang- undangan}

SAP merupakan acuan wajib dalam menyajikan laporan keuangan entitas pemerintah, baik pemerintah pusat maupun daerah. Pengguna laporan keuangan menggunakan SAP untuk dapat memahami informasi yang disajikan dalam laporan keuangan. Sedangkan auditor eksternal menggunakan SAP sebagai kriteria dalam melaksanakan audit. Dengan demikian SAP digunakan sebagai penyatu persepsi antara pengguna dan auditor laporan keuangan. SAP yang berlaku di Indonesia ditetapkan dengan PP Nomor 24 Tahun 2005 tanggal 13 Juni 2005 dengan pembaruannya PP Nomor 71 Tahun 2010. PP ini menjadi landasan bagi semua entitas pelaporan termasuk pemerintah daerah dalam menyajikan laporan keuangan sebagai pertanggungjawaban kepada berbagai pihak.

\section{Status Daerah}

Dalam Undang-Undang Dasar (UUD) RI Tahun 1945 Pasal 18B ayat (1) disebutkan bahwa "Negara mengakui dan menghormati satuan-satuan pemerintah daerah yang bersifat khusus atau bersifat istimewa yang diatur undang-undang. Pandangan bahwa jenis daerah mempengaruhi kelengkapan pengungkapan dikarenakan adanya perbedaan karakteristik masyarakat dan struktur pendapatan berimplikasi pada kontrol sosial yang berbeda pula (Abdullah, 2004)

\section{Ukuran Daerah}

Ukuran (size) organisasi banyak digunakan sebagai bagian dari karateristik suatu organisasi, baik dalam bentuk perusahaan maupun pemerintah lokal.Ukuran organisasi menunjukan besar kecilnya suatu organisasi. Banyak penelitian menggunakan berbagai indikator untuk menentukan ukuran organisasi. Ukuran organisasi dapat diukur dari total aset, 
jumlah karyawan yang dimiliki, jumlah produksi yang dihasilkan maupun total pendapatan. Damanpour (1991) dan Patrick (2007) mengungkapkan bahwa ukuran organisasi merupakan bagian dari struktur organisasi

\section{Opini Laporan Keuangan}

Sebagaimana yang telah diatur di dalam Undang-Undang No.15 Tahun 2004 tentang Pemeriksaan Pengelolaan dan Tanggung Jawab Keuangan Negara, BPK RI memberikan empat jenis opini, yaitu: Pendapat Wajar Tanpa Pengecualian (Unqualified Opinion). Pendapat Wajar Dengan Pengecualian (Qualified Opinion). Pendapat Tidak Wajar (Adverse Opinion), Pernyataan Menolak Memberikan Pendapat (Disclaimer Opinion).

Penelitian De Angelo (1981a) menunjukkan bahwa nilai temuan audit menunjukkan kemampuan auditor BPK-RI dalam mendeteksi kesalahan pada laporan keuangan pemerintah daerah. Temuan audit adalah total jumlah kasus temuan oleh BPK-RI yang terdiri dari: (1) kerugian daerah; (2) potensi kerugian daerah; (3) kekurangan penerimaan; (4) administrasi; (5) ketidakhematan; (6) ketidakefisienan; dan (7) ketidakefektifan. Temuan audit ini dilaporkan pada pengguna laporan keuangan dalam hal ini lembaga perwakilan (DPR) yang mewakili rakyat sebagai pengguna laporan keuangan, dan dikembalikan kepada pemerintah daerah untuk ditindaklanjuti sebagai umpan balik bagi perbaikan di masa yang akan datang. Opini yang dihasilkan oleh auditor merupakan hasil temuan audit.

\section{Pengembangan Hipotesis}

1) Ketepatan Waktu dan Opini Laporan Keuangan

Penelitian Primadita dan Fitriany (2012) menyatakan bahwa jangka waktu audit berpengaruh terhadap informasi asimetri. Menurut McLellan dan Giroux (2000), opini wajar dengan pengecualian (qualified opinion) merupakan sebuah pertanda kabar buruk bagi pengguna laporan keuangan. Hasil penelitian Payne dan Jensen (2000) menyebutkan opini wajar dengan pengecualian berpengaruh positif terhadap audit delay. Opini yang diberikan oleh BPK atas laporan keuangan pemerintah daerah berupa opini non WTP (yaitu WDP, TW, atau TMP) dapat dianggap sebuah catatan buruk kinerja keuangan pemerintah daerah yang bersangkutan. Semakin tepat waktu maka akan semakin baik opini laporan keuangan daerah yang didapatkan oleh pemerintah daerah. Berdasarkan urain di atas, maka hipotesis yang dapat dikembangkan:

$\mathrm{H}_{1}$ : Ketepatan waktu penyampaian laporan keuangan berpengaruh positif pada opini laporan keuangan pemerintah daerah.

2) Kelemahan Sistem Pengendalian Internal Pemerintah Daerah dan Opini Laporan Keuangan

Kawedar (2010) dalam penelitiannya menghubungkan tingkat kelemahan SPI dengan perubahan opini audit melalui metode kualitatif. Fatimah (2014) juga menemukan bahwa kelemahan sistem pengendalian internal berpengaruh negatif terhadap opini laporan keuangan. Kedua penelitian tersebut menghasilkan kesimpulan sejenis yang menyatakan bahwa perubahan opini audit yang semakin menurun dipengaruhi oleh semakin lemahnya pengendalian internal entitas. Berdasar uraian ini, dapat dikembangkan hipotesis:

$\mathrm{H}_{2}$ : Kelemahan Sistem Pengendalian

Internal Pemerintah Daerah berpengaruh negatif terhadap opini laporan keuangan pemerintah daerah.

3) Kepatuhan Terhadap PerundangUndangan dan Opini Laporan Keuangan

Pemerintah Auditor mengeluarkan opini audit dengan mempertimbangkan empat kriteria yang salah satunya adalah temuan kepatuhan entitas terhadap peraturan perundang-undangan. Sipahutar dan Khairani (2013) dalam kesimpulan penelitiannya juga mengungkapkan adanya pelanggaran yang material atas peraturan perundang-undangan serta ketidaksesuaian 
penyajian laporan keuangan sesuai peraturan yang berlaku. Peningkatan tingkat materialitas atas pelanggaran tersebut semakin melemahkan tingkatan opini audit dari WDP menjadi TW.

Berdasar uraian di atas, maka hipotesis yang dapat dikembangkan:

\section{$\mathrm{H}_{3}$ : Ketidakpatuhan Terhadap Perundang- undangan berpengaruh negatif pada opini laporan keuangan pemerintah daerah. \\ 4) Status Daerah dan Opini Laporan Keuangan}

Status daerah akan membedakan antara kota dan kabupaten. Masyarakat kota memiliki kontrol sosial yang lebih kuat (Abdullah, 2004) dalam Suhardjanto et al, 2010. Dengan adanya kontrol sosial tersebut, tuntutan gencar dilakukan oleh masyarakat kepada pemerintah agar terselenggara pemerintahan yang baik sejalan dengan meningkatnya pengetahuan masyarakat serta adanya pengaruh globalisasi menuntut adanya keterbukaan (Herminingsih,2009) dalam Suhardjanto et al, 2010. Dengan kontrol sosial tinggi yang dimiliki oleh masyarakat kota, maka akan semakin meningkatkan pengawasan mereka pada jalannya pemerintahan dan penggunaan anggaran pemerintah daerah, sehingga dengan adanya pengawasan tersebut pemerintah daerah akan berusaha untuk meningkatkan kinerjanya untuk jadi lebih baik Dari uraian di atas, maka hipotesis yang dikembangkan:

$\mathrm{H}_{4}$ : Status daerah berpengaruh positif pada opini laporan keuangan pemerintah daerah.

\section{5) Ukuran Pemerintah Daerah dan Opini Laporan Keuangan}

Menurut Cohen (2008), semakin besar ukuran daerah (size) maka masalah yang akan dihadapi semakin rumit dan pengelolaan sumber daya yang ada akan semakin tidak efisien, sehingga daerah yang memiliki ukuran daerah atau total aset yang besar akan memiliki tuntutan yang besar pula untuk bisa mengelola keuangan dengan baik agar mendapat opini laporan keuangan yang baik. Berdasar uraian ini, dapat dikembangkan hipotesis:

$\mathrm{H}_{5}$ : Ukuran pemerintah daerah berpengaruh negatif terhadap opini laporan keuangan pemerintah daerah.

\section{Metode Penelitian}

Berdasar kriteria yang telah ditentukan total sampel yang digunakan jumlahnya sebanyak 110 LKPD kota/kabupaten di pulau Jawa, artinya tidak semua populasi digunakan sebagai sampel. Nama-nama pemerintah daerah kota/kabupaten yang digunakan di dalam penelitian ini dapat dilihat di Lampiran I. Secara terinci, sampel setiap tahunnya disajikan dalam tabel berikut ini:

Tabel 4.1 Pemilihan Sampel Penelitian

\begin{tabular}{lc}
\hline \multicolumn{1}{c}{ Kriteria Pemilihan Sampel } & Jumlah \\
\hline Jumlah LPKD kota/kabupaten di pilau Jawa : & 112 \\
Tahun 2013 & 2 \\
Data tidak lengkap & $\mathbf{1 1 0}$
\end{tabular}

Sumber: Data diolah, 2016

Analisis dan Hasil

1. Statistik Deskriptif 
Analisis deskriptif memberikan gambaran umum mengenai data dan penyebaran data yang digunakan dalam penelitian ini. Penggambaran umum yang dijelaskan dalam analisis ini meliputi nilai rata-rata (means), nilai tertinggi (maksimum), nilai terendah (minimum) dan nilai penyimpangan atau penyebaran data (standar deviasi) dalam penelitian ini.

Tabel 1

Statistik Deskriptif

Descriptive Statistics

\begin{tabular}{lrrrrr}
\hline \hline & $\mathrm{N}$ & Minimum & Maximum & \multicolumn{1}{c}{ Mean } & Std. Deviation \\
\hline \hline Time & 110 & 80.00 & 183.00 & $1.3425 \mathrm{E} 2$ & 18.05163 \\
SPI & 110 & 2.00 & 15.00 & 6.6182 & 2.96766 \\
KPU & 110 & 2.00 & 14.00 & 6.2364 & 2.73586 \\
OPN & 110 & 1.00 & 4.00 & 3.2818 & .56067 \\
STATUS & 110 & .00 & 1.00 & .2545 & .43760 \\
LN_Size & 110 & 27.81 & 31.25 & 28.8076 & .56962 \\
Valid N (listwise) & 110 & & & & \\
\hline \hline
\end{tabular}

Sumber: Data diolah, 2016

Berdasar pada tabel deskriptif statistik menunjukkan nilai minimum ketepatan waktu penyampaian laporan keuangan Pemda di pulau Jawa pada tahun 2013 sebesar 80 hari yang dimiliki oleh Kabupaten Kebumen. Sedangkan nilai maksimum sebesar 183 hari yang dimiliki oleh kabupaten Sampangdan nilai rerata umur Pemda yaitu sebesar 134,25. Nilai standart deviasi sebesar 180,51 yang menunjukkan variasi sebaran data (range).

Sistem pengendalian intern dihitung dengan menggunakan jumlah temuan kelemahan SPI pada pemerikssaan audit BPK. Nilai minimum jumlah temuan kelemahan SPI oleh BPK yaitu 2 temuan. Sedangkan nilai maximum temuan kelemahan SPI sebesar 15 temuan di pemerintah kota/kabupaten di pulau Jawa tahun 2013. Dengan nilai rerata 6,61 dan standart deviasi 2,96 yang menunjukkan variasi sebaran data (range).

Kepatuhan terhadap peraturan perundangundangan dihitung dengan menggunakan jumlah temuan ketidakpatuhan pemerintah daerah terhadap perundang-undangan pada pemerikssaan audit BPK. Nilai minimum jumlah temuan ketidakpatuhan pemerintah JURNAL ILMIAH EKONOMI ISLAM, ISSN: 2477-6157 ; E-ISSN 2579-6534 daerah terhadap perundang-undangan oleh BPK yaitu 2 temuan. Sedangkan nilai maximum temuan temuan ketidakpatuhan pemerintah daerah terhadap perundang-undangan sebesar 14 temuan di pemerintah kota/kabupaten di pulau Jawa tahun 2013. Dengan nilai rerata 6,23 dan standart deviasi 2,73 yang menunjukkan variasi sebaran data (range).

Status daerah pada penelitian ini diukur dengan menggunakan skor, dengan ketentuan, jika status daerah adalah kabupaten maka akan diberi skor 0 dan jika status daerah adalah kota maka akan diberi skor 1 . Ada 28 kota dan 82 kabupaten di pulau Jawa. Dengan nilai rerata 0,254 dan standart deviasi 0,437 yang menunjukkan variasi sebaran data (range).

Proksi variabel ukuran daerah yang digunakan pada penelitian ini menggunakan logaritma total asset. Tahun 2013 total asset di pulau Jawa minimal sebesar 27,81 yang dimiliki oleh Kota Batu, maksimal 31,25 yang dimiliki oleh Kota Surabaya tahun 2013, nilai asset ratarata sebesar 28,65. Nilai standar deviasi sebesar 0,5983 dan yang menunjukkan variasi sebaran data (range). 
Variabel hasil audit dalam penelitian ini adalah opini laporan keuangan pemerintah daerah (OPN). Dalam penelitian ini digunakan skala 1 sampai dengan 4 untuk penilaian opini LKPD dengan penjelasan; Nilai 4 untuk opini WTP, nilai 3 untuk opini WDP, Nilai 2 untuk opini TW dan untuk nilai 1 untuk opini Disclaimer, yang kriteria nilai opini LKPD.
Distribusi sampel dalam penelitian ini ditunjukkan dalam tabel 4.3 case processing summary, dimana kondisi sampel ini menunjukkan gambaran penerimaan opini untuk masing-masing pemerintah daerah di pulau Jawa.

Tabel 2

Case Processing Summary

\begin{tabular}{lccc}
\hline \hline \multicolumn{4}{c}{ Case Processing Summary } \\
\hline \hline \multirow{2}{*}{ OPN } & & $\mathrm{N}$ & \\
& 1 & 2 & Marginal Percentage \\
& 3 & 73 & $1.8 \%$ \\
& 4 & 35 & $66.4 \%$ \\
Valid & & 110 & \\
Missing & & 0 & $100.0 \%$ \\
Total & 110 & \\
\hline \hline
\end{tabular}

Sumber: Data diolah, 2016

Dari hasil olah data tersebut dapat diartikan bahwa opini Tidak Memberikan Pendapat diberikan kepada 2 pemerintah daerah atau jika dipersentasekan sebesar 1,8\% dari keseluruhan sampel. Kemudian untuk opini Tidak Wajar diberikan kepada tidak ada Opini

\section{Analisis Data}

\section{Uji Kelayakan Model}

Menurut Ghozali (2011) uji kelayakan dari model merupakan probabilitas bahwa model yang dihipotesiskan menggambarkan
Wajar Dengan Pengecualian memiliki persentase yang paling tinggi yaitu $66,4 \%$ yaitu 73 pemerintah daerah. Terakhir adalah opini Wajar Tanpa Pengecualian sebesar 31,8\% atau berhasil diraih oleh 35 pemerintah daerah.

data input. Untuk dapat menilai model yang digunakan fit atau tidak digunakan fungsi likelihood yang ditransformasikan menjadi 2LogL.

Tabel 3

Model Fitting Information

\section{Model Fitting Information}

\begin{tabular}{lcccc}
\hline \hline Model & -2 Log Likelihood & Chi-Square & df & Sig. \\
Intercept Only & 156.052 & & & \\
Final & 140.101 & 15.950 & 5 & .007
\end{tabular}




\begin{tabular}{lcccc}
\hline \hline \multicolumn{4}{c}{ Model Fitting Information } & \\
\hline \hline Model & -2 Log Likelihood & Chi-Square & df & Sig. \\
Intercept Only & 156.052 & & \\
Final & 140.101 & 15.950 & 5 & .007 \\
& Link function: Logit. & & & \\
\hline \hline
\end{tabular}

Sumber: Data diolah, 2016

Dengan melihat tabel di atas penurunan Chi-Square sebesar 15,950 dan menunjukkan bahwa ketika hanya memasukkan signifikan pada $\mathrm{p}=0.007$. Dapat disimpulkan model intersep ternyata hasil 2 Log Likelihood bahwa model dengan variable independen sebesar 156,052. Kemudian dengan memberikan ketepatan akurasi yang lebih baik memasukkan variabel independen, 2 Log untuk memprediksi opini BPK.

Likelihood turun menjadi 140,101 atau terjadi

Tabel 4

Goodness-of-Fit

\begin{tabular}{lccc}
\hline \hline \multicolumn{3}{c}{ Goodness-of-Fit } & \\
\hline \hline \multirow{2}{*}{ Pearson } & Chi-Square & df & Sig. \\
Deviance & 207.584 & 213 & .592 \\
Link function: Logit. & 140.101 & 213 & 1.000 \\
\hline \hline
\end{tabular}

Sumber: Data diolah, 2016

Nilai Pearson yang dihasilkan adalah sebesar 0,592. Dapat disimpulkan bahwa model sebesar 207.584 dengan taraf signifikansi sesuai nilai sig.>0,05 (2011: 361).

Tabel 5

Test of Parallel Lines ${ }^{a}$

\begin{tabular}{lrrrr}
\hline \hline Model & -2 Log Likelihood & Chi-Square & df & Sig. \\
\hline \hline Null Hypothesis & 140.101 & & \\
General & 135.546 & 4.555 & 5 & .473 \\
The null hypothesis states that the location parameters (slope coefficients) are the same \\
across response categories. \\
a. Link function: Logit.
\end{tabular}

Sumber: Data diolah, 2016

Tujuan uji parallel lines adalah menilai apakah asumsi semua kategori memiliki parameter yang sama atau tidak (Ghozali 2011:363). Apabila hasil uji ini menunjukkan $\mathrm{p}<0,000$ maka diartikan model tidak sesuai. Model sesuai jika memiliki nilai yang tidak signifikan yaitu $p>0,05$. Dari hasil out put di 
atas nilai $\mathrm{p}$ sebesar 0,473 dan lebih besar dari 0,05 maka model dikatakan sudah sesuai.

Uji Koefisien Determinasi
Tujuan pengujian ini adalah untuk melihat seberapa besar persamaan regresi dapat menjelaskan variabel dependen.

Tabel 6

Pseudo R-Square

\begin{tabular}{lcc}
\hline & Pseudo R-Square & \\
\hline \hline Cox and Snell & .135 \\
Nagelkerke & .178 \\
McFadden & .102 \\
Link function: Logit. & \\
\hline \hline
\end{tabular}

Sumber: Data diolah, 2016

Berdasarkan Tabel 6 diketahui bahwa besarnya variasi nilai opini yang dapat dijelaskan oleh model regresi adalah sebesar 0,102 atau 10,2\%. Dengan kata lain 10,2\% variasi nilai opini merupakan kontribusi pengaruh kelemahan SPI, ketidakpatuhan

\section{Menguji Koefisien Regresi}

terhadap perundang-undangan, ukuran total asset, ketergantungan Pemerintah Daerah, dan opini periode sebelumnya. Sedangkan sisanya $89,8 \%$ dijelaskan oleh variabel diluar model.

Tabel 7

Parameter Estimates

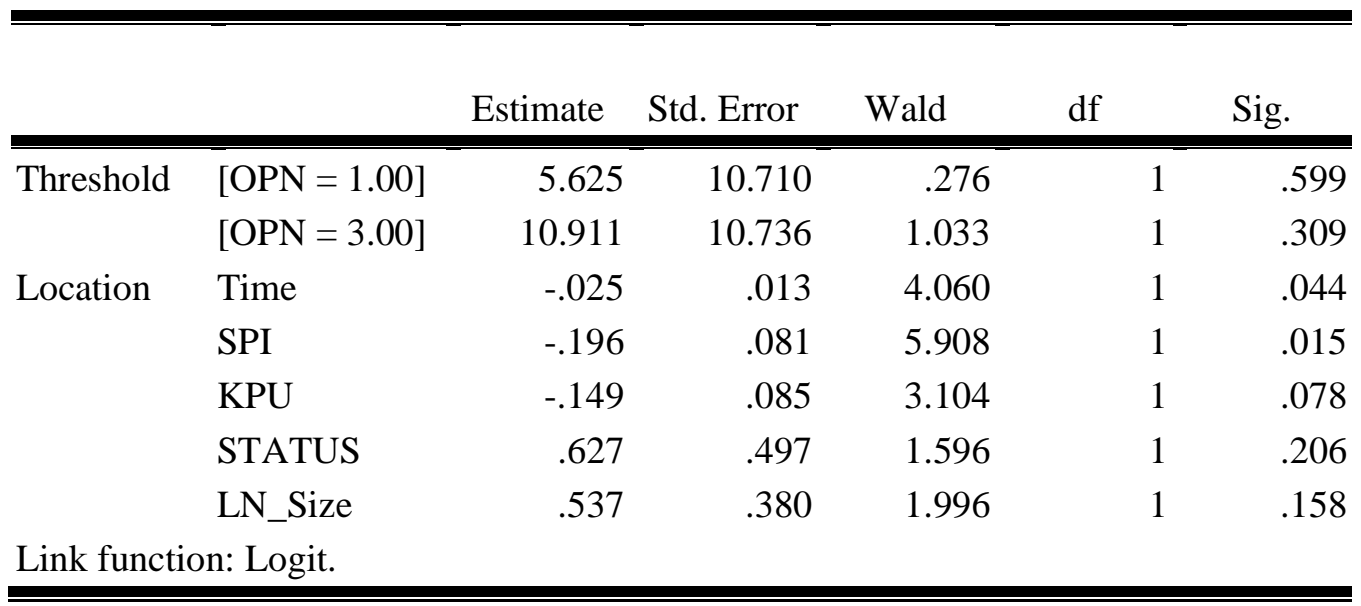

Sumber: Data diolah, 2016

Dari hasil regresi dapat disimpulkan bahwa ada 3 variabel yang berpengaruh signifikan terhadap opini laporan keuangan pemerintah daerah yaitu ketepatan waktu penyampaian laporan keuangan, system pengendalian internal dan kepatuhan terhadap perundang-undangan tetapi khusus untuk kepatuhan terhadap perundang-undangan menggunakan nilai signifikasi $10 \%$. Sedangkan 2 variabel lain yaitu status daaerah dan ukuran JURNAL ILMIAH EKONOMI ISLAM, ISSN: 2477-6157 ; E-ISSN 2579-6534 daerah tidak berpengaruh terhadap opini laporan keuangan pemerintah daerah di pulau Jawa tahun 2013.

Dari ringkasan hasil analisis pada Tabel. 7 diatas dapat disusun persamaan regresi sebagai berikut:

Logit $(\mathrm{p} 1)=5,625-0,025$ Time - 0,196 SPI 0,149 KPU + 0,627 STATUS + 0,537 LN_Size

\section{Pembahasan}




\section{Ketepatan waktu penyampaian laporan keuangan dan opini laporan keuangan pemerintah daerah}

Dari hasil uji regresi variabel ketepatan waktu penyampaian laporan keuangan mempunyai signifikasi sebesar 0,044 dengan yang berarti nilai siginfikasi variabel ketepatan waktu penyampaian laporan keuangan lebih kecil dari 0,05 sehingga variabel ketepatan waktu penyampaian laporan keuangan berpengaruh signifikan terhadap opini laporan keuangan pemerintah daerah. Hipotesis 1 diterima. Hal ini menunjukana bahwa ketepatan waktu penyampaian laporan keuangan memiliki pengaruh signifikan terhadap opini laporan keuangan pemerintah daerah. Sesuai penelitian Payne dan Jensen (2000) menyebutkan opini wajar dengan pengecualian berpengaruh positif terhadap audit delay. Semakin lama penyampaian laporan keuangan menunjukan kualitas laporan keuangan semakin kurang baik.

\section{Kelemahan sistem pengendalian internal pemrintah daerah dan opini laporan keuangan pemerintah daerah}

. Dari hasil uji regresi variabel sistem pengendalian internal mempunyai signifikasi sebesar 0,015 dengan yang berarti nilai siginfikasi variabel sistem pengendalian internal lebih kecil dari 0,05 sehingga variabel sistem pengendalian internal berpengaruh signifikan terhadap opini laporan keuangan pemerintah daerah. Hipotesis 2 diterima. Hal ini menunjukana bahwa sistem pengendalian internal memiliki pengaruh signifikan terhadap opini laporan keuangan pemerintah daerah. Hasil ini sesuai dengan penelitian Fatimah (2014) yang menemukan bahwa kelemahan sistem pengendalian internal berpengaruh negatif terhadap opini laporan keuangan.

Dalam melaporkan kelemahan pengendalian internal atas pelaporan keuangan, pemeriksa BPK harus dapat mengidentifikasi "kondisi yang dapat dilaporkan" yang secara sendiri-sendiri maupun kumulatif merupakan kelemahan yang material. Pemeriksa harus menempatkan identifikasi tersebut menjadi suatu temuan dalam perspektif yang wajar (SPKN, 2007). Untuk memberikan dasar bagi pengguna laporan hasil pemeriksaan dalam mempertimbangkan kejadian dan konsekuensi kondisi tersebut, hal yang diidentifikasi harus dihubungkan dengan hasil pemeriksaan secara keseluruhan. Sejalan dengan definisi wajar menurut standar pemeriksaan tersebut, auditor BPK diharuskan menggunakan pertimbangan profesionalnya dalam menentukan apakah telah terjadi kasus kelemahan pengendalian internal atau tidak, serta apakah temuan tersebut dirasa cukup material untuk dilaporkan atau tidak.

\section{Kepatuhan terhadap peraturan perundang-undangan dan opini laporan keuangan pemerintah daerah \\ Dari hasil uji regresi variabel kepatuhan} terhadap peraturan perundang-undangan mempunyai signifikasi sebesar 0,078 dengan yang berarti nilai siginfikasi variabel kepatuhan terhadap peraturan perundang-undangan lebih besar dari 0,05 tetapi peneliti ,manggunakan tingkat signifikasi $10 \%$ sehingga variabel kepatuhan terhadap peraturan perundangundangan berpengaruh signifikan terhadap opini laporan keuangan pemerintah daerah. Hipotesis 2 diterima. Hal ini menunjukana bahwa kepatuhan terhadap peraturan perundangundangan memiliki pengaruh signifikan terhadap opini laporan keuangan pemerintah daerah. Hasil ini sesuai dengan penelitian Kwedar (2010) dan Fatimah (2014) yang menemukan bahwa kelemahan sistem pengendalian internal berpengaruh negatif terhadap opini laporan keuangan. Semakin banyak ketidakpatuhan terhadap perundangan atas laporan keuangan yang dilaporkan akan semakin mendapatkan opini yang tidak baik dari BPK.

\section{Ukuran daerah dan opini laporan keuangan pemerintah daerah}

Ukuran pemerintah daerah (total aset) organisasi banyak digunakan sebagai bagian dari karateristik suatu organisasi, baik dalam bentuk perusahaan maupun pemerintah lokal.Ukuran organisasi menunjukan besar kecilnya suatu organisasi. Banyak penelitian menggunakan berbagai indikator untuk menentukan ukuran organisasi. Ukuran organisasi dapat diukur dari total aset, jumlah karyawan yang dimiliki, jumlah produksi yang JURNAL ILMIAH EKONOMI ISLAM, ISSN: 2477-6157 ; E-ISSN 2579-6534 
dihasilkan maupun total pendapatan. Damanpour (1991) dan Patrick (2007) mengungkapkan bahwa ukuran organisasi merupakan bagian dari struktur organisasi. Dari hasil uji regresi variabel ukuran daerah mempunyai signifikasi sebesar 0,158 dengan yang berarti nilai siginfikasi variabel ukuran daerah lebih besar dari 0,05 sehingga variabel ukuran daerah tidak berpengaruh signifikan terhadap opini laporan keuangan pemerintah daerah. Hipotesis 4 ditolak. Hal ini menunjukana bahwa ukuran daerah memiliki tidak berpengaruh terhadap opini laporan keuangan pemerintah daerah.

\section{Status daerah dan opini laporan keuangan pemerintah daerah}

Status daerah di indonesia identik dengan penggunaan istilah kabupaten dan kota. Menurut Peraturan Menteri Dalam Negeri Nomor 2 Tahun 1987 tentang Pedoman Penyusunan Rencana Kota pasal 1 yang dimaksud dengan kota adalah pusat pemukiman dan kegiatan penduduk yang mempunyai batasan administrasi yang diatur dalam perundang-undangan, serta permukiman yang telah memperlihatkan watak dan ciri kehidupan perkotaan, sedangkan kabupaten adalah pembagian wilayah administratif di Indonesia setelah provinsi. Kabupaten adalah daerah otonom yang diberi wewenang mengatur dan mengurus urusan pemerintahannya sendiri dan kabupaten merupakan hierarki terendah dari pembagian administratif indonesia di bawah pemerintah propinsi (disebut daerah tingkat kedua). Dari hasil uji regresi variabel status daerah mempunyai signifikasi sebesar 0,206 dengan yang berarti nilai siginfikasi variabel status daerah lebih besar dari 0,05 sehingga variabel status daerah tidak berpengaruh signifikan terhadap opini laporan keuangan pemerintah daerah. Hipotesis 5 ditolak. Hal ini menunjukana bahwa status daerah memiliki tidak berpengaruh terhadap opini laporan keuangan pemerintah daerah.

\section{Kesimpulan}

Penelitian ini bertujuan untuk memberikan bukti empiris tentang pengaruh ketepatan waktu penyampaian laporan keuangan, kelemahan sistem pengendalian internal pemerintah daerah, kepatuhan terhadap peraturan perundang-undangan, ukuran daerahdan status daerah terhadap opini laporan keuangan pemerintah daerah. Dengan menggunakan 110 sampel LKPD tahun 2013 di pulau Jawa. Berdasarkan hasil analisis dan pengujian hipotesis yang telah dilakukan maka hasil penelitian dapat disimpulkan sebagai berikut:

1. Variabel ketepatan waktu penyampaian laporan keuangan memberikan bukti empiris bahwa variabel pertama yaitu ketepatan waktu penyampaian laporan keuangan berpengaruh negatif terhadap opini laporan keuangan pemerintah daerah di pulau Jawa. Hasil uji regresi menunjukan nilai signifikasi variabel ukuran daerah $0,044<0,05$.

2. Variabel sistem pengandalian internal pemerintah daerah memberikan bukti empiris bahwa variabel kedua yaitu sistem pengandalian internal berpengaruh negatif opini laporan keuangan pemerintah daerah di pulau Jawa. Hasil uji regresi menunjukan nilai signifikasi variabel sistem pengandalian internal pemerintah daerah $0.015<0,05$.

3. Variabel kepatuhan terhadap peraturan perundang-undangan memberikan bukti empiris bahwa ketiga variabel yaitu kepatuhan terhadap peraturan perundangundangan berpengaruh terhadap opini laporan keuangan pemerintah daerah di pulau Jawa dengan tingkat signifikasi 10\%. Hasil uji regresi menunjukan nilai signifikasi variabel kepatuhan terhadap peraturan perundang-undangan $0,078<0,10$.

4. Variabel status daerah memberikan bukti empiris bahwa variabel keempat yaitu status daerah tidak berpengaruh terhadap opini laporan keuangan pemerintah daerah opini laporan keuangan pemerintah daerah di pulau Jawa. Hasil uji regresi menunjukan nilai variabel keempat yaitu status daerah $0,206>0,05$.

5. Variabel ukuran pemerintah daerah memberikan bukti empiris bahwa variabel 
kelima yaitu ukuran pemerintah daerah tidak berpengaruh terhadap opini laporan keuangan pemerintah daerah opini laporan keuangan pemerintah daerah di pulau Jawa. Hasil uji regresi menunjukan nilai variabel kelima yaitu ukuran pemerintah daerah $0,158>0,05$.

\section{Keterbatasan}

Penelitian ini memiliki beberapa keterbatasan yang dapat menyebabkan penarikan kesimpulan penelitian ini menjadi kurang sempurna yaitu dalam hal yang berkaitan dengan periode pengamatan penelitian ini terbatas selama 1 tahun dengan jumlah 110 LKPD pemerintah daerah kabupaten/kota di pulau Jawa.

\section{Saran}

Berdasarkan hasil analisis dan pembahasan pengujian hipotesis penelitian ini, maka dapat disampaikan beberapa saran bagi penelitian selanjutnya dengan tema sejenis sebagai berikut:

1. Memperpanjang periode pengamatan sampel penelitian sehingga dapat diperoleh jumlah sampel yang lebih representatif. Penggunaan sumber data sekunder yang hanya berasal dari BPK, ini dimaksudkan agar penelitian selanjutnya yang menggunakan sumber data yang sama dapat memperpanjang periode pengamatannya dengan data yang digunakan dalam penelitian ini.

2. Untuk penelitian selanjutnya, peneliti merekomendasikan untuk menambah variabel independen lainnya, mengingat bahwa model regresi yang digunakan dalam penelitian ini hanya mampu menjelaskan sebesar $10,2 \%$ saja atas variabel dependen.

\section{Daftar Pustaka}

Abdullah, Syukriy. 2004. Perilaku oportunistik legislatif dalam penganggaran daerah: Pendekatan Principal-Agent Theory. Makalah disajikan pada Seminar Antarbangsa di Universitas Bengkulu, Bengkulu, 4-5 Oktober 2004

Atyanta, R. 2011. Analisis Opini BPK atas Laporan Keuangan Pemerintah Daerah
(Studi Kasus pada Kabupaten $\mathrm{X}$ di Jawa Timur).Jurnal Ilmiah 1 (1): 16.

Badan Pemeriksa Keuangan. 2015. Laporan Hasil Pemeriksaan Semester 1. Diakses melaluiwww.bpk.go.id

Cohen, S and N Kaimenakis. 2008. An Empirical Investigation of Greek Municipalities' Quality of Financial Reporting. Working paper series

Fatimah, D., Ria N. S. dan M. Rasuli. 2014. Pengaruh Sistem Pengendalian Intern, Kepatuhan Terhadap Peraturan Perundang-Undangan, Opini Audit Tahun Sebelumnya dan Umur Pemerintah Daerah Terhadap Penerimaan Opini Wajar Tanpa Pengecualian Pada Laporan Keuangan Pemerintah Daerah Di Seluruh Indonesia. Jurnal Akuntansi 3 (1): 1 - 15

DeAngelo, L. E. 1981. Auditor size and audit quality. Journal of Accounting and Economics, 3(3): 113-127.

Ghozali, Imam. 2011. Ekonometrika: Teori, Konsep dan Aplikasi dengan SPSS 17. Cetakan 2 Penerbit UNDIP

Halim, Abdul dan Muhammad Syam Kusufi. 2012. Akuntansi Keuangan Daerah, Penerbit Salemba.

Haryanto, Sahmuddin, Arifuddin, 2007, Akuntasi Sektor Publik, Semarang, Badan Penerbit UNDIP

Harun. 2009. Reformasi Akuntansi dan Manajemen Sektor Publik di Indonesia. Penerbit Salemba Empat

Herminingsih, 2006. Pengaruh Partisipasi dalam Penganggaran dan Peran Manajerial Pengelola Keuangan Daerah terhadap Kinerja Pemerintah Daerah (Studi Empiris pada Pemerintah Kabupaten Demak). Tesis Universitas Diponegoro Semarang

Indrarti, Nuansa Mega Okky. 2011. Hubungan antara Opini Audit pada Laporan Keuangan Daerah, Pendapatan Asli Daerah (PAD) dan Dana Alokasi Umum (DAU) terhadap Kinerja Keuangan Daerah. Jurnal. Universitas Riau.

Jiang, W., K. H. Rupley dan J. Wu. 2009. Internal Control Deficiencies and the 
Issuance of Going Concern Opinions. Research in Accounting Regulation 22: 40-46.

Johnson, L. E., 1998. Further evidence on the determinants of local government audit delay. Journal of Public Budgeting, Accounting and Financial Management, 103: 375-397.

Kawedar, W. 2010. Opini Audit dan Sistem Pengendalian Intern (Studi Kasus di Kabupaten PWJ yang Mengalami Penurunan Opini Audit).Jurnal Akuntansi dan Auditing 6:8.

Mustikarini, Widya Astuti., Fitriasari, Debby. 2012. 'Pengaruh Karakteristik Pemerintah Daerah dan Temuan Audit BPK terhadap Kinerja Pemerintah Daerah Kabupaen/Kota di Indonesia Tahun Anggaran 2007'. Simposium Nasional Akuntansi XV: Banjarmasin.

Patrick, P. A. 2007. The Determinant of Organizational Inovativeness: The Adoption of GASB 34 in Pennsylvania Local Government. Unpublished Ph.D Dissertation. Pennsylvania: The Pennsylvania State University.

Peraturan Menteri Negara Pendayagunaan Aparatur Negara Nomor: PER/05/M.PAN/03/2008 Tentang Standar
Audit Aparat Pengawasan Intern Pemerintah.

Peraturan Pemerintah Republik Indonesia Nomor 60 Tahun 2008 Tentang Sistem

Pengendalian Intern Pemerintah

Poerwadarminta. 2006. Kamus Umum Bahasa Indonesia. Edisi ketiga. Jakarta: Balai Pustaka

Robbins,W.A dan Austin, K.R. 1987. Disclousure quality in Govermental Financial Reports: an Asseeement of The Appropriateness of a Compound Measure. Journal of Accounting Research Vol 24, pp 412-421.

Sekaran, Uma dan Bougie Roger. 2010. Research Method for Business, A Skill Building Approach. Fifth Edition, New York, John Willey\&Son Inc.

Suhardjanto, Djoko., Rusmin, Mandasari., Putriesti., dan Brown, Alistair. 2010. 'Mandatory Disclosure Compliance and Local Government Charactheristics: Evidence From Indonesian Municipalities'. Journal Public Policy January 2010

Virgasari, Aviva. 2009. Hubungan Antara Opini Auditor pada Laporan Keuangan Daerah, Pendapatan Asli Daerah(PAD) dan Dana Alokasi Umum (DAU) dengan Kinerja Keuangan Daerah 